Endocrinol. Japon. 1987, 34 (6), 887-896

\title{
Expression of Renin and Angiotensinogen Genes in the Human Placental Tissues
}

\author{
Yoshiyuki IHARA, Shunzo TAII and TAKahide MORI \\ Department of Gynecology and Obstetrics, Kyoto University \\ Faculty of Medicine, Sakyo-ku, Kyoto 606, Japan
}

\begin{abstract}
The expression of renin and angiotensinogen genes in the human placenta and related tissues has been examined by RNA blot hybridization analysis with specific human complementary DNA (cDNA) probes. Renin mRNA was detectable in the chorion throughout pregnancy and in the hydatidiform moles, but not in the decidua, amnion or myometrium. The relative concentration of renin mRNA in the chorion was at the highest level in early pregnancy and decreased thereafter, while the total amount contained in the whole placenta was at the lowest level in early pregnancy, and increased thereafter, reaching at term about one-sixth of the total renin mRNA in the kidney. Hydatidiform moles had an even higher concentration of renin mRNA than the early chorion. There was no significant difference in either the relative concentration or the total renin mRNA content in the placentae from 4 normal and 4 toxemic pregnancies. Angiotensignogen mRNA was undetectable in any of the placental tissues, hydatidiform moles or myometrium. These results show that renin is synthesized in the placenta, possibly to play some physiological role locally by utilizing angiotensinogen which is abundantly present in the maternal systemic circulation.
\end{abstract}

The renin-angiotensin system (R-A system) is known to play an important role in the systemic regulation of sodium balance and blood pressure (Oparil and Harber, 1974; Peach, 1977). In addition, recent evidence has demonstrated that a local R-A system besides a systemic one is present in some organs such as the brain

\section{Received March 17, 1987}

This study was supported in part by a research grant from the Ministry of Education, Science and Culture of Japan. Address for correspondence: Dr. Yoshiyuki IHARA, Department of Gynecology and Obstetrics, Kitano Hospital, Kamiyama-cho 13-3, Kitaku, Osaka 530, Japan.
(Ganong, 1984 ; Steele et al., 1981 ; Steele et al., 1983). Renin has also been suggested to be synthesized in the placenta because of the presence of renin activity in the homogenates of the placental tissues or in the medium of cultured explants from the placenta (Symonds et al., 1968; Skinner et al., 1968; Warren et al., 1982). Furthermore, Poisner et al. localized renin in the chorion by immunohistochemistry (Poisner et al., 1981). However, these studies have only demonstrated the presence of renin activity or renin-like substance in the placenta, rather than its synthesis within the placenta. 
As to definitive proof of the biosynthesis, Acker et al. demonstrated the biosynthesis of inactive renin in the human chorionic cell culture by pulse labeled experiments (Acher et al., 1982), and Soubrier et al. detected renin mRNA in the human chorion by RNA hybridization analysis with human renin cDNA probe (Soubrier et al., 1983).

In the present study, we have attempted to examine whether angiotensinogen gene in addition to renin gene is expressed in the placenta, and if so, how they change quantitatively during the course of pregnancy, in order to understand the physiological role of these regulatory substances in a view of the local R-A system.

\section{Materials and Methods}

\section{Materials}

Placentae in the first and the second trimester were obtained after artificial abortions performed legally according to the Eugenic Protection Law of Japan for medical or social reasons. Two hydatidiform moles (complete mole) were obtained after therapeutic curettage. The placentae of 4 uncomplicated full term pregnant women and 4 full term subjects complicated with toxemia (gestosis with hypertension, edema or proteinuria) were obtained after spontaneous vaginal delivery or elective caesarian section. Among the placental tissues obtained, chorion (chorion frondosum) was prepared by dissecting away both the maternal surface (decidua) and fetal surface (amnion) from the placenta. The decidua was collected by intrauterine curettage after delivery. Amnion and chorion laeve were removed carefully from the fetal membranes. The uterine myometrium was obtained from a patient undergoing hysterectomy because of massive hemorrhage after delivery. The histological purity of the chorion, decidua and amnion obtained was confirmed with a micros:ope. The kidneys and the livers of 2 non-pregnant woman were obtained from autopsies. All materials were collected after obtaining informed consent.

These tissues and organs were immediately cooled on ice, rinsed with cold saline, quickly frozen in liquid nitrogen, and then stored at $-80^{\circ} \mathrm{C}$ until the extraction of RNA.

\section{RNA preparations}

Total RNA was extracted by the guanidinethiocyanate method as described by Chirgwin et al. (1979). The yield of total RNA ranged from 300 to $480 \mu \mathrm{g} / \mathrm{g}$ tissue. Poly (A)-enriched RNA was prepared by subjecting the total RNA preparation to oligo (dT)-cellulose column chromatography (Aviv and Leder, 1972). The yield of poly (A)-enriched RNA was from 4.1 to $5.4 \%$ of total RNA. In the case of early pregnancy (from 8 to 18 weeks), each placenta was so small for RNA extraction that one RNA sample was prepared from several ( 2 to 4 ) placentae.

\section{$R N A$ hybridization analysis}

The poly (A)-enriched RNA was denatured by incubation at $50^{\circ} \mathrm{C}$ for $60 \mathrm{~min}$ in $10 \mathrm{mM}$ sodium phosphate buffer $\mathrm{pH} 7.0$ containing $1 \mathrm{M}$ glyoxal and $50 \%$ dimethylsulfoxide, and electrophoresed on $1.5 \%$ agarose gel in $10 \mathrm{mM}$ sodium phosphate buffer pH 7.0 (McMaster and Carmichael, 1977). The separated RNA on gel was transferred to diazobenzyloxymethyl paper (DBM paper) according to the method of Alwine et al. (1977). The paper was prehybridized at $42^{\circ} \mathrm{C}$ for $24 \mathrm{hr}$ in prehybridization buffer $(50 \%$ formamide, $0.75 \mathrm{M} \mathrm{NaCl}, 0.075 \mathrm{M}$ sodium citrate, $50 \mathrm{mM}$ sodium phosphate buffer, pH $7.0,0.02 \%$ polyvinylpyrrolidone, $0.02 \%$ Ficoll, $0.02 \%$ bovine serum albumin, $1 \%$ glycine, $0.2 \%$ sodium dodecyl sulfate and $100 \mu \mathrm{g}$ denatured salmon sperm DNA per $\mathrm{ml}$ ). The paper was then hybridized at $42^{\circ} \mathrm{C}$ for $24 \mathrm{hr}$ in the same solution except that glycine was omitted and that the solution contained ${ }^{32}$ p-labelled specific human renin or angiotensinogen cDNA probe. The renin cDNA probe was the $P s t$ I-Bst II fragment containing nucleotides 0 to 658 derived from the clone pHRn 321 (Imai et al., 1983). The angiotensinogen cDNA probe was the Bst EII fragment containing nucleotides -2 to 1260 derived from the clone pHag3 (Kageyama et al., 1984). Before hybridization the probes had been nick translated with $\alpha{ }^{32} \mathrm{P}-\mathrm{d}$ CTP (Peter et al., 1977), and the specific activity of the probes was $2-4 \times 10^{8} \mathrm{cpm} / \mu \mathrm{g}$.

After hybridization, the DBM paper was washed several times at $42^{\circ} \mathrm{C}$ for $2 \mathrm{hr}$ in a solution containing $0.45 \mathrm{M} \mathrm{NaCl}, 0.045 \mathrm{M}$ sodium citrate and $0.1 \%$ sodium dodecyl sulfate. The 
paper was blotted, covered with plastic wrap and subjected to autoradiography with an intensifying screen at $-80^{\circ} \mathrm{C}$ for $2-4$ days. The intensity of the hybridizable renin mRNA band with renin cDNA was measured by counting the radioactivity or scanning the density of the hybridization band, and quantified as the relative concentration of renin mRNA per unit amount of poly (A)-enriched RNA.

The total renin mRNA content in the whole placenta or the kidney was calculated as follows :

$$
\mathrm{A} \times \mathrm{B} \times \mathrm{C} / 100 \times \mathrm{D} / 10(\mathrm{cpm})
$$

$\mathrm{A}$, weight of the placenta or the kidney $(\mathrm{g})$; B, the yield of total RNA from the tissue $(\mu \mathrm{g} / \mathrm{g}$ tissue); C, the yield of poly (A)-enriched RNA from total RNA by oligo (dT)-cellulose (\%); D, the relative concentration of renin mRNA in the tissue $(\mathrm{cpm} / 10 \mu \mathrm{g}$ poly (A)-enriched RNA, shown in Fig. 3) (Table 1).

\section{Results}

Identification and localization of renin $m R N A$ in the human placental tissues by blot hybridization analysis.

Poly (A)-enriched RNA was prepared from the three compartments (i. e. amnion

\section{a b c d e f}

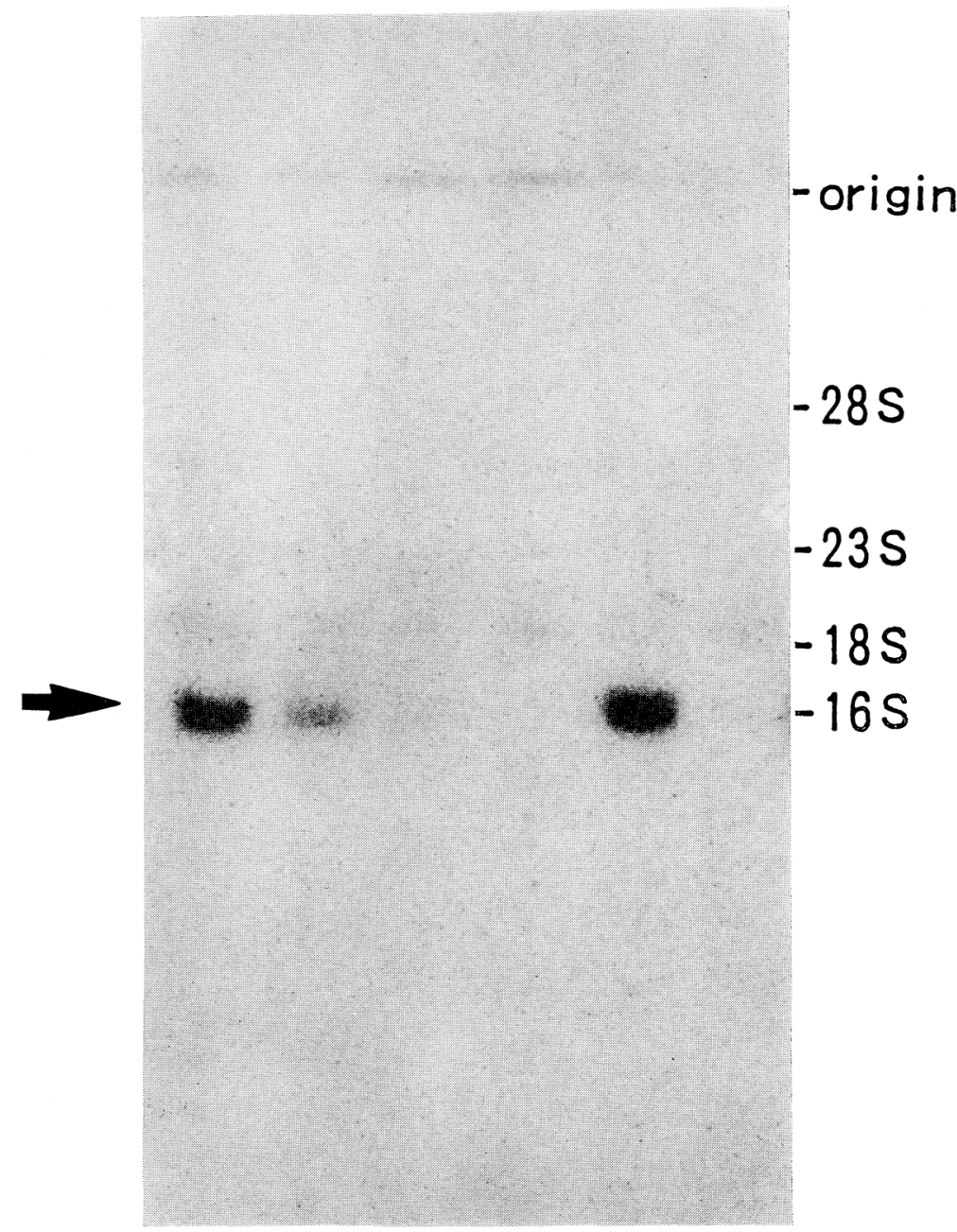

Fig. 1. Blot hybridization analysis of mRNAs from the placental tissues with the human renin cDNA as a probe.

Poly (A)-enriched RNAs were analysed by blot hybridization analysis with the human renin cDNA probe as described in Methods. The sources and amounts of poly (A) enriched RNA analysed were as follow: lane a, hydatidiform mole, $3 \mu \mathrm{g}$; lane $\mathrm{b}$, chorion, $10 \mu \mathrm{g}$; lane C, amnion, $10 \mu \mathrm{g}$; lane $\mathrm{d}$, decidua, $10 \mu \mathrm{g}$; lane e, the kidney, $3 \mu \mathrm{g}$; lane $\mathrm{f}$, myometrium, $10 \mu \mathrm{g}$. Chorion, amnion and decidua were obtained from the normal placenta in the third trimester.

The arrow on the left indicates the position of human renin mRNA, with mobility corresponding to approximately 1600 nucleotides in length. The size markers used were human rRNA (28S, 18S) and Escherichia coli rRNA (23S, 16S). 

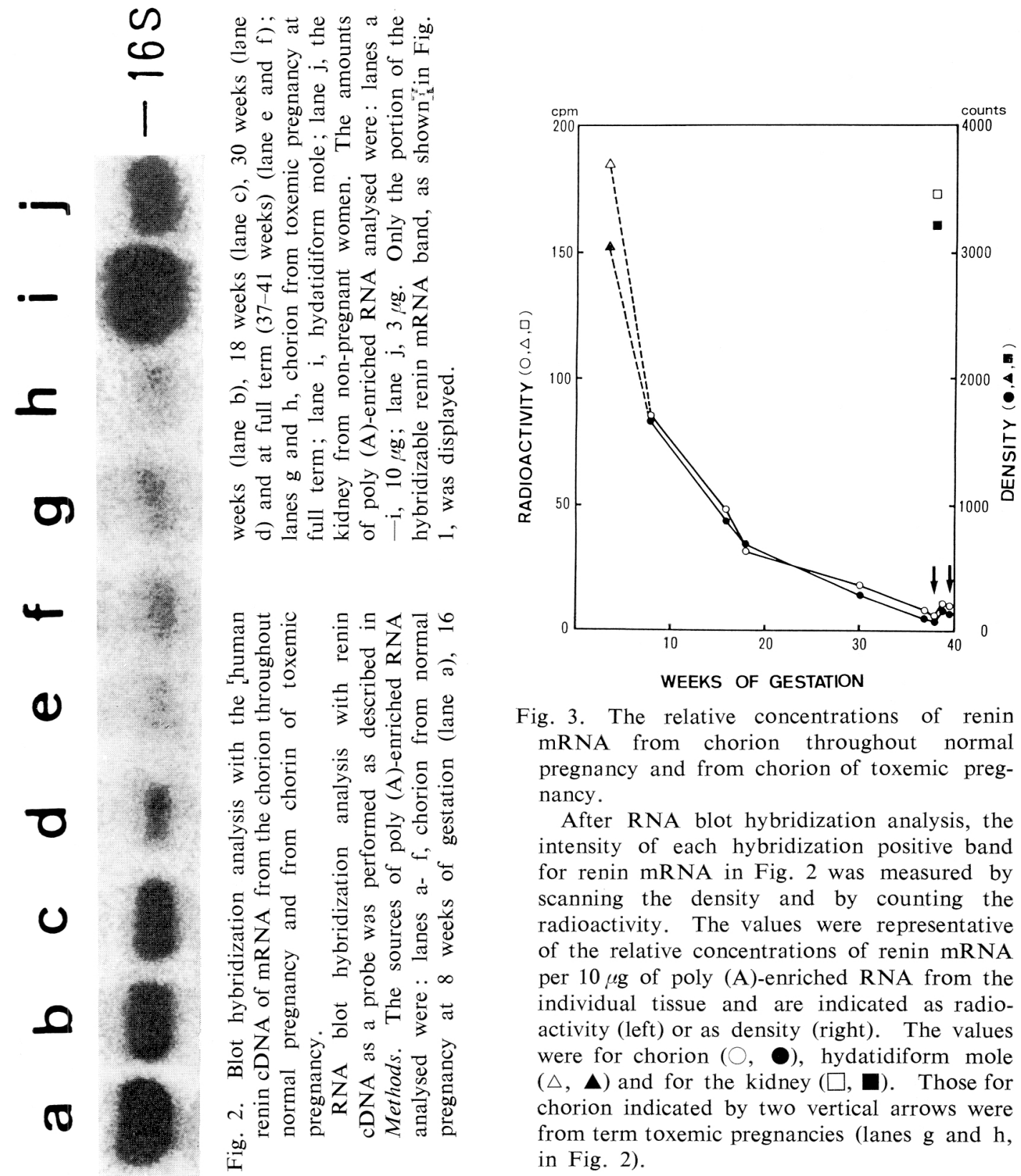

Fig. 3. The relative concentrations of renin mRNA from chorion throughout normal pregnancy and from chorion of toxemic pregnancy.

After RNA blot hybridization analysis, the intensity of each hybridization positive band for renin mRNA in Fig. 2 was measured by scanning the density and by counting the radioactivity. The values were representative of the relative concentrations of renin mRNA per $10 \mu \mathrm{g}$ of poly (A)-enriched RNA from the individual tissue and are indicated as radioactivity (left) or as density (right). The values were for chorion $(\bigcirc, \boldsymbol{\theta})$, hydatidiform mole $(\triangle, \mathbf{\Delta})$ and for the kidney $(\square, \boldsymbol{\square})$. Those for chorion indicated by two vertical arrows were from term toxemic pregnancies (lanes $\mathrm{g}$ and $\mathrm{h}$, in Fig. 2). 
chorion and decidua) of the human placenta in the third trimester, hydatidiform mole, and from myometrium. The result of blot hybridization analysis of mRNA obtained from these tissues is shown in Fig. 1. Chorion and hydatidiform mole, as well as the kidney, showed positive hybridization bands, but amnion, decidua or myometrium did not. Two portions of chorion, chorion frondosum and chorion laeve, showed hybridization bands of similar density; the band for chorion frondosum is displayed in Fig. 1. The position of the bands was identical to that of renin mRNA from the kidney, with mobility corresponding to approximately 1600 nucleotides in length (Imai et al., 1983). Thus, renin mRNA was demonstrated only in the chorionic tissues among the placental tissues.

Measurement of relative concentrations and total renin $m R N A$ contents in the placenta from normal and toxemic pregnancies

As shown in Fig. 2, the intensity of the renin mRNA band per $10 \mu \mathrm{g}$ poly (A)enriched RNA from the chorion was highest in early pregnancy, and decreased thereafter toward the end of pregnancy. RNA from hydatidiform moles showed an even more intense band of hybridization than that from the chorion in early pregnancy. There was no apparent difference in the intensities of the bands in term normal (lanes e and $f$ ) and toxemic pregnancies (lanes $\mathrm{g}$ and $\mathrm{h}$ ).

The intensity of each band of renin mRNA in Fig. 2, which shows the relative concentration of renin mRNA per unit amount of poly (A)-enriched RNA, was quantified by scanning the density or by counting the radioactivity (Fig. 3). The values obtained by the two different methods correlated well $(r=0.94)$. The relative concentration of renin mRNA in the chorion
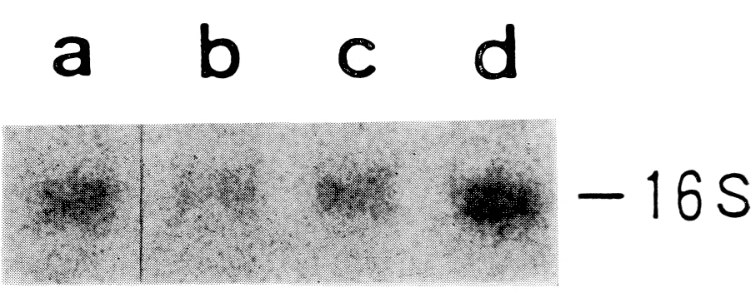

Fig. 4. The relative concentration of renin mRNA in the chorion of normal and toxemic pregnancies at term.

Blot RNA hybridization analysis was performd with the human renin cDNA probe as described in Methods. The sources of poly (A)-enriched RNA analysed were chorion of normal pregnancy (lane a and b) and chorion of toxemic pregnancy (lane $\mathrm{c}$ and $\mathrm{d}$ ) at fullterm. The amount of poly (A)-enriched RNA analysed was $10 \mu \mathrm{g}$ for each lane. Only the portion of hybridizable renin mRNA band was displayed, as in Fig. 2.

Table 1. The total renin mRNA content in the placenta and kidney.

\begin{tabular}{|c|c|c|c|c|c|}
\hline \multirow{2}{*}{ Tissue } & \multicolumn{4}{|c|}{ Placenta } & \multirow{2}{*}{ Kidney } \\
\hline & $8 \mathrm{~W}$ & $18 \mathrm{~W}$ & $30 \mathrm{~W}$ & 39W & \\
\hline A, weight $(\mathrm{g})$ & 9.8 & 102 & 320 & 482 & 216 \\
\hline $\mathrm{B}$, total RNA ( $\mu \mathrm{g} / \mathrm{g}$ tissue $)$ & 375 & 441 & 412 & 384 & 391 \\
\hline C, poly (A)-enriched RNA (\%) & 5.4 & 4.5 & 4.7 & 5.2 & 4.1 \\
\hline $\begin{array}{l}\mathrm{D} \text {, relative concentration of renin mRNA } \\
(\mathrm{cpm} / 10 \mu \mathrm{g} \text { poly (A) RNA) }\end{array}$ & 85.6 & 32.1 & 18.0 & 13.9 & 165 \\
\hline Total content of renin mRNA $(\mathrm{cpm})$ & 1699 & 6498 & 11154 & 13378 & 57134 \\
\hline
\end{tabular}

The total renin mRNA content was calculated as follows (as described in Methods):

$$
\mathrm{A} \times \mathrm{B} \times \mathrm{C} / 100 \times \mathrm{D} / 10(\mathrm{cpm})
$$

Relative concentration of renin mRNA (D) in each case was illustrated in Fig. 3 . In this table, the values for $\mathrm{A}, \mathrm{B}, \mathrm{C}$ and $\mathrm{D}$ from several representative cases are shown. The total renin mRNA content values thus obtained are plotted in Fig. 5. 


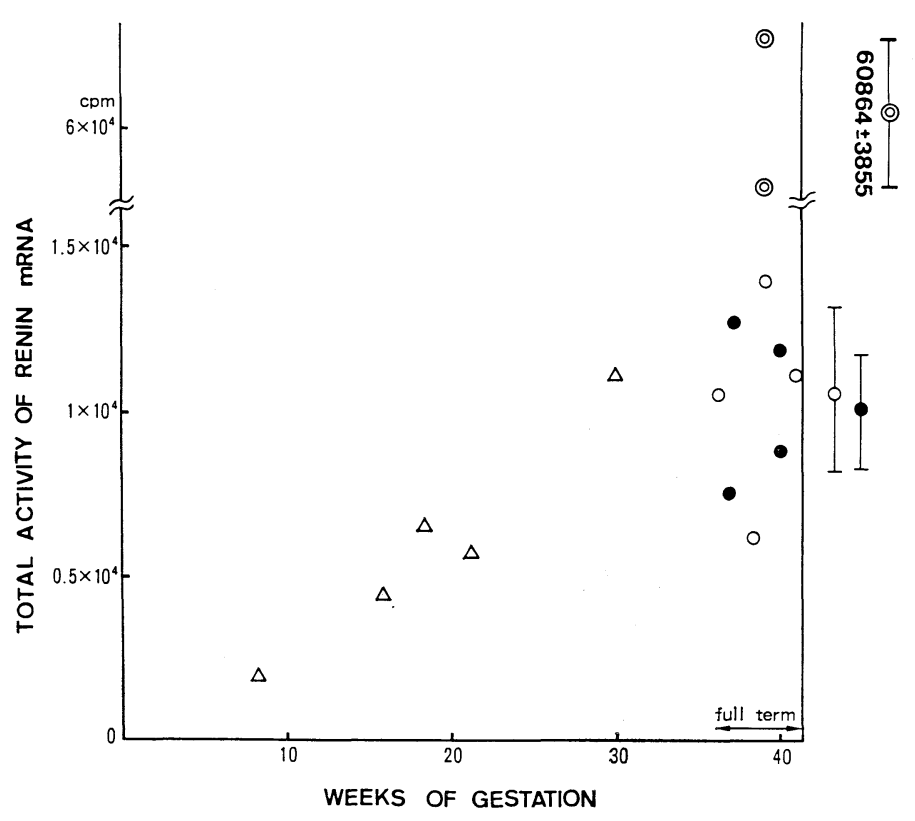

Fig. 5. The total renin mRNA content in the placenta throughout normal pregnancy and in the placenta of toxemic pregnancy.

The total renin mRNA content in the whole placenta was calculated from the radioactivity values for the relative concentration of renin mRNA per $10 \mu \mathrm{g}$ of poly (A)-enriched RNA (Fig. 3), values for the yield of total RNA and poly (A)-enriched RNA from the tissues and from wet weight of the tissues (Table 1). The values were for the placentae at 8 to 30 weeks of normal gestation $(\triangle)$, term placentae from normal pregnancy $(\bigcirc)$, term placentae from toxemic pregnancy (O) and for the kidneys (○). (The values for another four cases of normal and hypertensive pregnancies at full-term, shown in Fig. 4 and a value for a case at 22 weeks of gestation were added in addition to those in Fig. 2). The mean value and 1 standard deviation for these three groups are shown on the right.

was at the highest level in early pregnancy, and decreased thereafter toward the end of pregnancy, reaching to the lowest level in the full-term chorion with approximately one-tenth of that in early pregnancy. The relative concentration of renin $\mathrm{mRNA}$ in the early chorion was nearly half of that in the kidney. Furthermore, the hydatidiform mole showed an even higher concentration of renin mRNA than the chorion in early pregnancy and its relative concentration of renin mRNA was nearly equal to that of the kidney. Another hydatidiform mole showed a similar value (data not shown).

There was no significant difference in the relative concentrations of renin mRNA in the chorion from two normal and two toxemic pregnancies (lanes e to $h$ in Fig. 2). There was also no significant difference in the re- lative concentration of renin mRNA in the chorion from additional 2 cases of normal and 2 cases of toxemic pregnancies (Fig. 4).

As shown in Fig. 5, the total renin mRNA content contained in the whole placenta was at the lowest in early pregnancy and increased gradually towards late pregnancy, to appoximately $1 \times 10^{4} \mathrm{cpm}$ which was estimated as about one-sixth of that of the kidney (approximately $6 \times 10^{4} \mathrm{cpm}$ ). The total renin mRNA content in the placenta of 4 toxemic cases at term was not significantly different from that of 4 normal cases (Fig. 5).

Blot hybridization analysis of $m R N A$ from the human placental tissues with angiotensinogen $c D N A$

As shown in Fig. 6, no hybridization positive band was observed with RNA from 


\section{$\begin{array}{llllll}a & b & c & d & e & f\end{array}$}

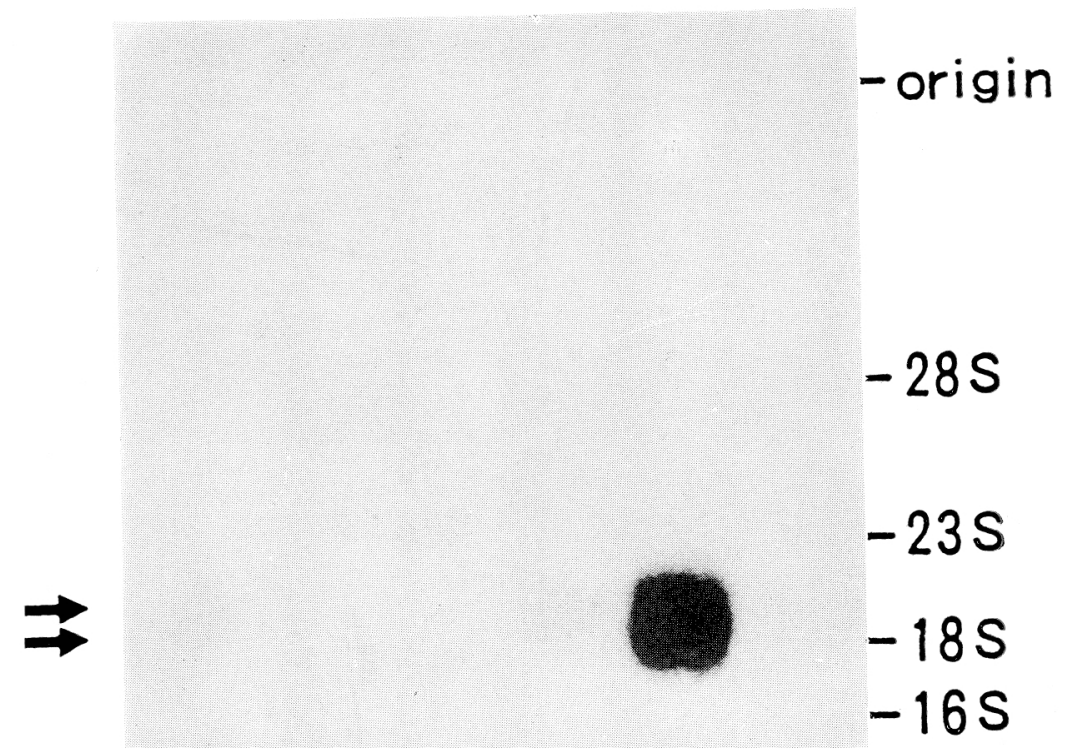

Fig. 6. Blot hybridization analysis of mRNAs from the human placental tissues with the human angiotensinogen cDNA probe.

Poly (A) - enriched RNAs from decidua (lane a), amnion (lane b), and chorion (lane c) of the third trimester human placenta, hydatidiform mole (lane d), the liver (lane e) and from myometrium (lane f) were analysed with the human angiotensinogen cDNA probe as described in Methods. The amount of poly (A)-enriched RNA analysed was $10 \mu \mathrm{g}$ for each lane. The two arrows on the left indicate the positions of the low and high molecular weight angiotensinogen mRNAs, which were approximately 2000 and 2200 nucleotides in length, respectively. The size markers used were the same as in Fig. 1.

any of the three compartments of the human placenta (amnion, chorion and decidua), from hydatidiform mole or from myometrium, except with RNA from the liver, which served as the control source of angiotensinogen.

\section{Discussion}

In the present study, RNA blot hybridization analysis revealed the presence of renin mRNA only in the chorionic tissues among the three different compartments of the human placenta and showed the changes not only in the relative concentration but also in the total renin mRNA content in the placenta throughout the course of pregnancy. The mRNA coding for angiotensinogen was not, however, present in the human placental tissues.

Since the R-A system is elevated in normal pregnancy (Weir et al., 1975; Skinner et al., 1975), chorion, decidua, amnion of the placenta and even myometrium have been suspected as candidates of extra-renal sources of renin during pregnancy because of the presence of renin activity in these tissues (Skinner et al., 1968; Warren et al., 1982; Skinner et al., 1975; Mulrow, 1977). However, the present investigation indicated that renin mRNA is present only in the chorion, and not in other placental tissues, the amnion or decidua, or myometrium, in agreement with the data on chorionic cell culture by Acker et al. (1982). Thus, the reports of the presence of renin activity in the amnion, decidua or uterine myometrium (Symonds et 
al., 1968; Skinner et al., 1968; Warren et al., 1982) may be due to the contamination or the diffusion of renin from the blood, amniotic fluid or from the chorion, rather than due to the actual synthesis of renin within these tissues.

Quantitatively marked changes were noted in the relative concentrations as well as in the total renin mRNA content in the human placenta throughout normal pregnancy. The relative concentration of renin mRNA in the chorion was at the highest level in early pregnancy, being ten times higher than that at full term, and decreased towards the end of pregnancy, although it may be partially due to the increased filtration to the chorion by vessels or fibroblasts. The total renin mRNA content in the whole placenta increased with the advance in gestational age, reaching at term approximately one-sixth of that in the kidney from non-pregnant woman. This means that the placenta should not be neglected as an additional extra-renal source of renin towards the end of pregnancy. Furthermore, a high renin mRNA concentration in hydatidiform mole, even higher than in the chorion of early pregnancy is quite compatible with the reports of elevated plasma renin activity in some cases of large hydatidiform moles (Mulrow, 1977).

No angiotensinogen mRNA was detected in the placental tissues by RNA blot hybridization analysis with the specific human angiotensinogen cDNA probe. Therefore, the source of the increased plasma level of angiotensinogen during pregnancy (Weir et al., 1975) could be the liver, where synthesis of angiotensinogen is stimulated by the effect of the increased concentration of plasma estrogen during pregnancy (Oelkers et al., 1976).

Most of placental renin is thought to be in an inactive form (Warren et al., 1982; Acker et al., 1982), and the presence of renin mRNA in the chorion does not directly indicate the production of active renin there.
However, the generation of angiotensin I by chorion in vitro was reported (Craven et al., 1983) and administered angiotensinogen, as well as angiotensin II, affects fetal perfusion pressure on perfused placenta (Glance et al., 1984). Moreover, it has been suggested that the activity of angiotensinconverting enzyme, which is present in virtually all mammalian organs (Richard, 1981), is present in the placenta (Glance et al., 1984). Thus, we speculate that the placenta has a local R-A system independent of the systemic R-A system : placental renin can hydrolyze angiotensinogen present in abundance in the circulation of pregnant woman to produce angiotensin I and the resultant angiotensin I may consequently be converted to angiotensin II, which can finally function in the placenta. Placental renin may play a role in the regulation of the fetoplacental circulation (Glance et al., 1984; Symonds et al., 1984), or exert a modulative effect on hCG secretion from the placenta, assuming an analogous situation in the brain in which angiotensin II plays a modulating role in LH secretion from the pituitary gland (Ganong, 1984 ; Steele et al., 1983).

The involvement of R-A system in the pathogenesis of toxemic pregnancy is still a subject of controversy. In pregnancy-induced hypertension or toxemia, the R-A system activity has been reported to be elevated (Annat et al., 1978), suppressed (Weir et al., 1973 ; Weir et al., 1975) or not significantly different from that in normal pregnancy (Symonds et al., 1984 ; Galley et al., 1980). These discrepancies may partly be due to the clinical tests for evaluating the R-A system. For example, values for PRA (plasma renin activity), which is most commonly measured, easily fluctuate depending on factors such as sodium intake in foods, loading of exercise, posture of body and various drugs administered (Haber, 1969). Moreover, since renin has been found to be synthesized in the placenta, systemic and probably local effects produced by renal and placental renin, 
respectively, should be evaluated and discussed individually. In the present study, no significant difference was found in either the relative concentration or the total renin mRNA content in normal and toxemic placentae. Therefore, it seems unlikely that the extent of renin synthesis in the placenta is directly involved in the pathogenesis of pregnancy-induced hypertension or toxemia, although the possibility of participation in its pathogenesis of the processes subsequent to renin synthesis (Symonds et al., 1984 ; Pipkin and Symonds, 1977)-for example, angiotensin converting activity in the placentashould be clarified in the future.

\section{Acknowledgements}

We thank Dr. S. Nakanishi and Dr. K. Murakami for generous gifts of valuable renin and angiotensinogen cDNA probes and their helpful advice.

\section{References}

Acker, G. M., F. X. Galen, C. Devaux, S. Foote, E. Papernik, A. Pestry, J. Menard and P. Corvol (1982). Human chorionic cells in primary culture: A model for renin biosynthesis. J. Clin. Endocrinol. Metab. 55, 902909.

Alwine, J. C., D. J. Kemp and G. R. Stark (1977). Method for detection of specific RNAs in agarose gels by transfer to diazobenzyloxymethyl-paper and hybridization with DNA probes. Proc. Natl. Acad. Sci. USA 74, 5350-5354.

Annat, G., D. Raudrant, J. Chappe, M. Vincent, J. Thoulon, M. Dumonte and J. Sassard (1978). Maternal and fetal plasma renin and dopamine$\beta$-hydroxylase activity in toxemic pregnancy. Obstet. Gynecol. 52, 219-224.

Aviv., H. and P. Leder (1972). Purification of biologically active globulin messenger RNA by chromatography on oligothymidylic acid cellulose. Proc. Natl. Acad. Sci. USA 69, 14081412 .

Chirgwin, J. M., A. E. Przybyla, R. J. MacDonald and W. J. Rutter (1979). Isolation of biologically active ribonucleic acid from sources enriched in ribonuclease. Biochemistry 18, 5294-5299.

Craven, D. J., A. Y. Warren and E. M. Symonds (1983). Generation of angiotensin I by human chorion-decidua in vitro. Am. J. Obstet. Gynecol. 145, 744-748.

Galley, E. D. M., G. S. Stokes, A. Z. Gyory, J. Rowe and J. Williams (1980). Plasma renin activity in normal human pregnancy and pregnancy-associated hypertension, with reference to cryoactivation. Clin. Sci. 59, 4953.

Ganong, W. F. (1984). The brain renin-angiotensin system. Ann. Rev. Physiol. 46, 17-31. Glance, D. G., M. G. Elder, D. L. Bloxam and L. Myatt (1984). The efiects of the components of the renin-angiotensin system on the isolated perfused human cotyledon. Am. J. Obstet. Gynecol. 149, 450-454.

Haber, E. (1969). Application of a radioimmunoassay for angiotensin I to the physiologic measurements of plasma renin activity in normal human subjects. J. Clin. Endocrinol. Metab. 29, 1349-1355.

Imai, T., H. Miyazaki, S. Hirose, H. Hori, T. Hayashi, R. Kageyama, H. Ohkubo, S. Nakanishi and K. Murakami (1983). Cloning and sequence analysis of cDNA for human renin precursor. Proc. Natl. Acad. Sci. USA 80, 7405-7409.

Kageyama, R., H. Ohkubo and S. Nakanishi (1984). Primary structure of human preangiotensinogen deduced from the cloned cDNA sequence. Biochemistry 23, 3603-3609.

Karlberg, B. E., G. Ryden and K. Wichman (1984). Changes in the renin-angiotensinaldosterone and kallikrein-kinin system during normal and hypertensive pregnancy. Acta Obstet. Gynecol. Scand. Suppl. 118, 17-24.

McMaster, G. K. and G. C. Carmichael (1977). Analysis of single and double-stranded nucleic acids on polyacrylamide and agarose gels by using glyoxal and acridine orange. Proc. Natl. Acad. Sci. USA 74, 4835-4838.

Mulrow, P. J. (1977). Renin aldosterone system in pregnancy. In: Fuchs, F., Klopper, A. (eds) Endocrinology of Pregnancy. Harper and Row, Hagerstown, 177-190.

Oelkers, W., A. Blümel, M. Schöneshöfer, U. Schwarz and J. Hammerstein (1976). Effects of ethinylestradiol on the renin-angiotensinaldosterone system and on plasma transcortin 
in women and men. J. Clin. Endocrinol. Metab. 43, 1036-1040.

Oparil, S. and E. Haber (1974). The reninangiotensin system. N. Engl. J. Med. 291, 389-401.

Peach, M. J. (1977). Renin-angiotensin system : Biochemistry and mechanism of action. Physiol. Rev. 57, 313-370.

Peter, W. J. R., D. Marianne, R. Carl and B. Paul (1977). Labeling deoxyribonucleic acid to high specific activity in vitro by nick translation with DNA polymerase I. J. Mol. Biol. 113, 237-251.

Pipkin, F. B. and E. M. Symonds (1977). Factors affecting angiotensin II concentrations in the human infant at birth. Clin. Sci. Mol. Med. 52, 499-506.

Poisner, A. M., G. W. Wood, R. Poisner and T. Inagami (1981). Localization of renin in trophoblasts in human chorion laeve at term pregnancy. Endocrinology 109, 1150-1155.

Richard, L. S. (1981). Biochemical regulation of blood pressure-angiotensin converting enzyme. John Wiley and Sons, New York, 24-28.

Skinner, S. L., E. Lumbers and E. M. Symonds (1968). Renin concentration in human fetal and maternal tissues. Am. J. Obstet. Gynecol. 101, 529-533.

Skinner, S. L., E. S. Cran, R. Gibson, R. Taylor, W. A. W. Watters and K. J. Catt (1975). Angiotensins I and II, active and inactive renin, renin substrate, renin activity and angiotensinogens in human liquor amnii and plasma. Am. J. Obstet. Gynecol. 121, 626630.

Soubrier, F., J. J. Panthier, P. Corvol and F. Rougeon (1983). Molecular cloning and nucleo- tide sequence of a human renin cDNA fragment. Nucleic Acids Research II, 7180-7190.

Steele, M. K., A. Negro-Vilar and S. M. McCann (1981). Effect of angiotensin II on in vivo and in vitro release of anterior pituitary hormones in the female rat. Endocrinology 109, 893-899.

Steele, M. K., R. V. Gallo and W. F. Ganong (1983). A possible role for the brain reninangiotensin system in the regulation of $\mathrm{LH}$ secretion. Am. J. Physiol. 245, R805-810.

Symonds, E. M., M. A. Stanley and S. L. Skinner (1968). Production of renin by in vitro cultures of human chorion and uterine muscle. Nature 217, 1152-1153.

Symonds, E. M., G. D. Lamming and D. J. Craven (1984). The fetal renin-angiotensin system in pregnancy-induced hypertension. $B r$. J. Obstet. Gynaecol. 91, 3-6.

Warren, A. Y., D. J. Craven and E. M. Symonds (1982). Production of active and inactive renin by cultured explants from the human female genital tract. Br. J. Obstet. Gynaecol. 89, 628-632.

Weir, R. J., J. J. Brown, R. Fraser A. Kraszewski, A. F. Lever, G. M. Mcllwaine, J. J. Morton, J. I. S. Robertson and M. Tree (1973). Plasma renin, renin substrate, angiotensin II and aldosterone in hypertensive disease of pregnancy. Lancet 1, 291-294.

Weir, R. J., J. J. Brown, R. Fraser, A. F. Lever, R. V. Logan, J. J. Morton, J. I. S. Robertson and M. Tree (1975). Relationship between plasma renin, renin-substrate, angiotensin II, aldosterone and electrolytes in normal pregnancy. J. Clin. Endocrinol. Metab. 40, 108-115. 